\title{
Originals
}

\section{Evidence of delayed $\beta$-cell destruction in Type 1 (insulin-dependent) diabetic patients with persisting complement-fixing cytoplasmic islet cell antibodies}

\author{
A. Mustonen ${ }^{1}$, M. Knip ${ }^{1}$, N.-P. Huttunen ${ }^{1}$, R. Puukka ${ }^{2}$, M.-L. Käär ${ }^{1}$ and H. K. Åkerblom ${ }^{1,3}$ \\ Departments of ${ }^{1}$ Paediatrics and ${ }^{2}$ Clinical Chemistry, University of Oulu, and ${ }^{3}$ Children's Hospital, University of Helsinki, Helsinki, Finland
}

\begin{abstract}
Summary. Forty-four children with Type 1 (insulin-dependent) diabetes (aged 0.7-16.7 years) were observed from diagnosis for cytoplasmic islet cell antibodies and serum C-peptide concentrations. Islet cell antibodies were analysed by indirect immunofluorescence for both conventional $\mathrm{IgG}$ and complement-fixing antibodies. Thirty-seven children (84\%) were found to be positive for conventional islet cell antibodies at diagnosis, and $21(48 \%)$ remained positive over the observation period. Twenty-six patients $(59 \%)$ were positive for complement-fixing antibodies at diagnosis and eight remained so during the follow-up period. The serum C-peptide concentrations increased significantly during the first 3 months after diagnosis, after which there was a gradual decrease in the levels. Those children who remained positive for complement-fixing antibodies over the observation period had significantly high-
\end{abstract}

er serum C-peptide concentrations on several occasions during the second year and had also a higher integrated serum C-peptide concentration over the initial 2 years than those who became negative for complement-fixing antibodies. These observations suggest that the continuous production of complement-fixing islet cell antibodies in those patients who are positive for these antibodies at diagnosis presupposes the preservation of a sufficient amount of functioning $\beta$ cells for antigenic stimulation. These results support the view that the complement-fixing islet cell antibodies reflect ongoing destructive processes in the $\beta$ cells.

Key words: Type 1 diabetes, complement-fixing islet cell antibodies, endogenous insulin secretion.
The prevalence of cytoplasmic islet cell antibodies (ICA) in Type 1 (insulin-dependent) diabetes mellitus decreases with increasing duration, but their role in the pathomechanism of the disease, if any, is unknown [1, 2]. When introducing the concept of complement-fixing (CF) ICA, Bottazzo et al. found these to be more closely related to the onset of insulin dependency than the conventional ICA (ICA-IgG) [3] and hence they suggested that CF-ICA reflect the active $\beta$-cell damage. The prevalence of ICA-IgG varies from $50 \%$ to $88 \%$ at onset, while that of CF-ICA is lower, as some patients with ICA-IgG are negative for CF-ICA. Also, CF-ICA disappear at an earlier stage in the disease than ICA-IgG $[3,4]$. It has been suggested in recent reports that the presence of CF-ICA may be of some value in predicting Type 1 diabetes [5-7], and these antibodies have even been shown to appear years before the clinical onset of the disease $[5,8]$.

Many diabetic children still have endogenous insulin secretion after the diagnosis of diabetes $[9,10]$. The residual $\beta$-cell function may be of clinical significance for the first few years after onset by facilitating good metabolic control. No relationship has been found pre- viously between endogenous insulin secretion and cytoplasmic ICA [11-14]. We have, however, recently demonstrated an association between CF-ICA and endogenous insulin secretion in a cross-sectional study comprising 184 diabetic children [15].

Some diabetic patients have in their serum material with complement-dependent cytotoxicity in vitro [16-18]. Hence, it has been suggested that CF-ICA may contribute to the selective $\beta$-cell damage in Type 1 diabetes. If this were the case one would expect the presence of CF-ICA to be related to accelerated $\beta$-cell destruction. The present study was therefore aimed at elucidating the possible role of cytoplasmic ICA in the $\beta$-cell destruction which occurs in the early stages of Type 1 diabetes.

\section{Subjects and methods}

\section{Subjects}

The study included the 44 children ( 24 boys) who were admitted to the Department of Paediatrics, University of Oulu, from May 1979 to June 1981 for initial treatment of diabetes mellitus. Their mean \pm 
SEM age at diagnosis was $9.4 \pm 0.7$ years (range $0.7-16.7$ years) and the mean duration of symptoms before diagnosis was $3.1 \pm 0.4$ weeks $(0-10$ weeks). On admission, 19 patients had no ketosis or acidosis, one had ketosis without acidosis (Ketostix in plasma positive), 19 had mild ketoacidosis (Ketostix in plasma positive: $7.15<\mathrm{pH}<7.35$ ) and five had severe ketoacidosis ( $\mathrm{pH} \leqslant 7.15$ ). Treatment was commenced with short-acting highly purified porcine insulin, with the aim of correcting the metabolic derangement within 1-3 days. Later treatment aimed at optimal metabolic control and clinical well-being. All patients were seen regularly at intervals of $1-3$ months. So far no autoimmune disease has been diagnosed in any of the children. Clinical remission is defined as the period which occurs shortly after the onset of diabetes when the daily insulin requirement is $<0.5 \mathrm{U} / \mathrm{kg}$ and glycosuria is absent or minimal. Minimal glycosuria presupposes a glycosuria index $>85 \%$. The glycosuria index expresses the percentage of
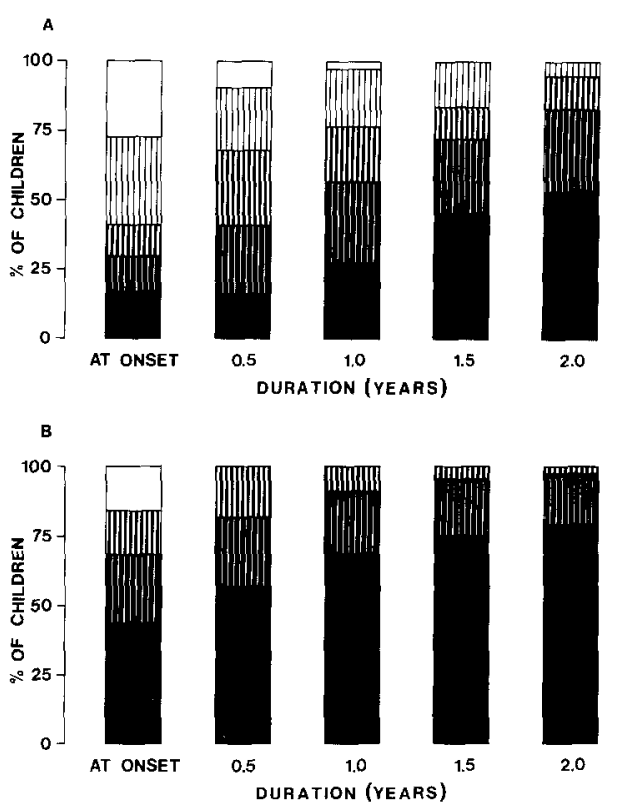

Fig. 1. A and B Changes in the titres of ICA-IgG $\left(A: \chi_{\mathrm{df}=16}^{2}=64.2\right.$; $p<0.001)$ and in the titres of CF-ICA $\left(B: \chi_{\mathrm{d} f}^{2}=12=42.6 ; p<0.001\right)$ over the initial 2 years in 44 diabetic children. ICA - ; IIIIICA + in un-

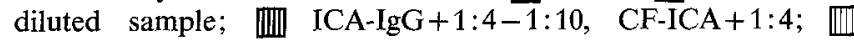
ICA-IgG + 1:20-1:40; $\square$ ICA-IgG $+>1: 80 ;$ CF-ICA + > 1:10 urine tests showing $<1 \%$ of glucose, based on all tests performed at home over the interval between two out-patient visits.

The first blood sample for the assay of ICA was taken before the initiation of insulin therapy when C-peptide and glycosylated haemoglobin $\left(\mathrm{HbA}_{1 \mathrm{c}}\right)$ levels were also measured. The following two samples for C-peptide and $\mathrm{HbA}_{1 \mathrm{c}}$ determinations were taken in the morning, before insulin injection, 10 days and 3 weeks after the commencement of insulin treatment. Blood samples for the C-peptide and $\mathrm{HbA}_{1 \mathrm{c}}$ assay were obtained subsequently every 3 months from diagnosis, in the post-prandial state between 10.00 and $12.00 \mathrm{~h}$ (i.e. between breakfast and lunch).

\section{Methods}

Serum C-peptide was measured according to Heding [19] using antiserum M 1230 (Novo Research Institute, Copenhagen, Denmark). Antibody-bound proinsulin was separated from the C-peptide by polyethylene glycol before assay [20]. The sensitivity of the assay was $0.02 \mathrm{nmol} / \mathrm{l}$ and the interassay coefficient of variation $10 \%$. An individual integrated serum $C$-peptide concentration for 24 months was calculated from the sum of the products of the mean serum C-peptide concentrations during each time period, multiplied by the duration of that time period. $\mathrm{HbA}_{1 \mathrm{c}}$ was measured in duplicate on $0.7 \times 20 \mathrm{~cm}$ columns packed with Bio Rex 70 resin (Bio Rad Laboratories, Richmond, California, USA) of 200-400 mesh [21]. The reference range of $\mathrm{HbA}_{1 \mathrm{c}}$ in non-diabetic children was $4.1-6.3 \%$, whereas the interassay coefficient of variation was $3.2 \%$.

ICA measurements were made at diagnosis and at least every 6 months thereafter, using both the conventional indirect immunofluorescence test and the complement-fixation test, by techniques described previously $[1,3,15]$. Fluoresceinated rabbit anti-human-IgG (Behringwerke, Marburg, FRG) diluted $1: 40$ with $\mathrm{NaCl}(0.154 \mathrm{~mol} / \mathrm{l})$ was used for the detection of ICA-IgG and rabbit anti-human C3c (Behringwerke) in the same dilution in the complement-fixation test. A dilution series was made of each positive serum sample to assess the titre. To evaluate the methods for measuring ICA titres, 10 samples from two subjects were studied repeatedly on a 'blind' basis. The reproducibility proved to be good, with a maximal variation of one dilution and no overlapping between positive and negative samples.

Thirty-nine patients were observed for up to 2 years with respect to ICA, C-peptide and $\mathrm{HbA}_{1 \mathrm{c}}$ levels, and five were observed for at least 1.5 years at which time four out of the five patients had no detectable ICA in their serum. The patients were classified into three subgroups according to the presence of ICA-IgG (group 1) and CF-ICA

Table 1. Age at diagnosis, duration of symptoms before diagnosis, degree of ketoacidosis at diagnosis and occurrence and duration of clinical remission and integrated serum C-peptide concentration over the initial 2 years in three groups of diabetic children classified on the basis of conventional islet cell antibody (groups $1 \mathrm{~A}, 1 \mathrm{~B}$ and $1 \mathrm{C}$ ), and in three groups classified on the basis of complement-fixing antibody (groups $2 \mathrm{~A}$, $2 \mathrm{~B}$ and 2C)

\begin{tabular}{|c|c|c|c|c|c|c|c|c|}
\hline & $\begin{array}{l}\text { Group } 1 \mathrm{~A} \\
(\mathrm{ICA}-\mathrm{IgG}+) \\
(n=21)\end{array}$ & $\begin{array}{l}\text { Group 1 B } \\
\text { (ICA-IgG+ } \\
\rightarrow--) \\
(n=16)\end{array}$ & $\begin{array}{l}\text { Group } 1 \mathrm{C} \\
\text { (ICA-IgG-) } \\
(n=7)\end{array}$ & Statistical analysis & $\begin{array}{l}\text { Group 2A } \\
(\mathrm{CF}-\mathrm{ICA}+) \\
(n=8)\end{array}$ & $\begin{array}{l}\text { Group 2 B } \\
\text { (CF-ICA+ } \\
\rightarrow--) \\
(n=18)\end{array}$ & $\begin{array}{l}\text { Group 2C } \\
(\text { CF-ICA-) } \\
(n=17)\end{array}$ & Statistical analysis \\
\hline Age at diagnosis (years) & $9.4 \pm 0.6$ & $9.3 \pm 1.2$ & $9.6 \pm 2.2$ & $\mathrm{~F}_{\mathrm{df}=2.41}=0.01 ; \mathrm{NS}$ & $10.4 \pm 1.5$ & $8.4 \pm 1.1$ & $10.3 \pm 1.1$ & $\mathrm{~F}_{\mathrm{df}=2.40}=0.91 ; \mathrm{NS}$ \\
\hline $\begin{array}{l}\text { Duration of symptoms } \\
\text { (weeks) }\end{array}$ & $2.6 \pm 0.6$ & $4.1 \pm 0.6$ & $2.6 \pm 1.9$ & $\mathrm{H}_{\mathrm{df}=2}=6.52 ; p<0.05$ & $4.0 \pm 1.4$ & $2.4 \pm 0.5$ & $3.5 \pm 0.6$ & $\mathrm{H}_{\mathrm{df}=2}=1.34 ; \mathrm{NS}$ \\
\hline $\begin{array}{l}\text { Comparison between } \\
\text { groups }\end{array}$ & & & & $\begin{array}{l}\text { Group 1 A versus } \\
\text { group 1 B } p<0.05\end{array}$ & & & & \\
\hline $\begin{array}{l}\text { Ketoacidosis at } \\
\text { diagnosis }[n,(\%)]\end{array}$ & $7(33)$ & $12(75)$ & $5(71)$ & $\mathrm{X}_{\mathrm{df}=2}^{2}=7.32 ; p<0.05$ & $4(50)$ & $10(56)$ & $9(53)$ & $\mathrm{X}_{\mathrm{df}=2}^{2}=0.07 ; \mathrm{NS}$ \\
\hline $\begin{array}{l}\text { Occurrence of clinical } \\
\text { remission }[n,(\%)]\end{array}$ & $16(76)$ & $11(69)$ & $6(86)$ & $X_{\mathrm{d} f=2}^{2}=0.78 ; \mathrm{NS}$ & $7(88)$ & $13(72)$ & $12(71)$ & $\mathrm{X}_{\mathrm{df}=2}^{2}=0.90 ; \mathrm{NS}$ \\
\hline $\begin{array}{l}\text { Duration of clinical } \\
\text { remission (days) }\end{array}$ & $238 \pm 54$ & $155 \pm 35$ & $258 \pm 51$ & $\mathrm{H}_{\mathrm{df}=2}=1.98 ; \mathrm{NS}$ & $211 \pm 50$ & $206 \pm 58$ & $205 \pm 42$ & $\mathrm{H}_{\mathrm{df}=2}=0.30 ; \mathrm{NS}$ \\
\hline $\begin{array}{l}\text { Integrated C-peptide } \\
\text { (nmol/1, } 24 \text { months) } \\
\text { Comparison between } \\
\text { groups }\end{array}$ & $4.68 \pm 0.68$ & $2.70 \pm 0.67$ & $5.55 \pm 1.36$ & $\mathrm{H}_{\mathrm{df}=2}=4.72 ; \mathrm{NS}$ & $5.93 \pm 1.19$ & $3.15 \pm 0.74$ & $4.30 \pm 0.72$ & $\begin{array}{l}\mathrm{H}_{\mathrm{df}=2}=6.15 \\
p<0.05 \\
\text { Group 2A versus } \\
\text { group 2 B } p<0.05\end{array}$ \\
\hline
\end{tabular}




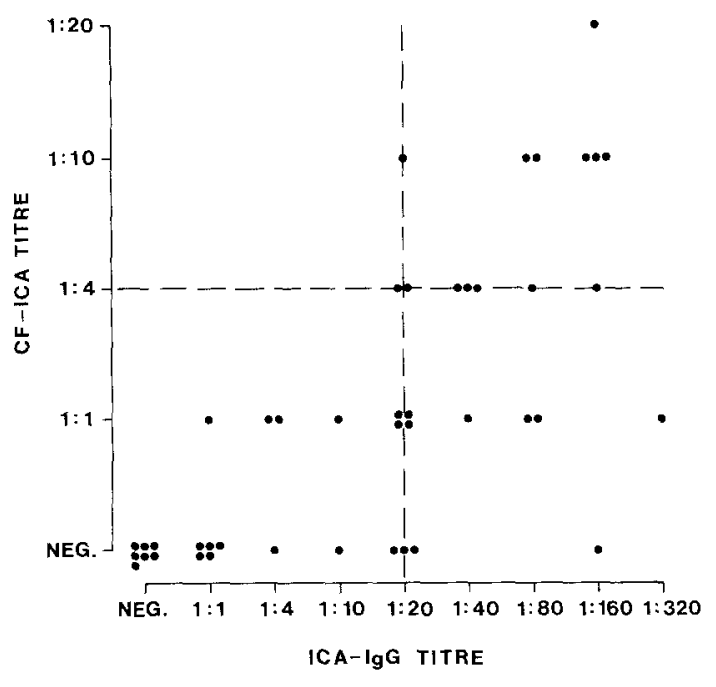

Fig. 2. Relationship between the titres of ICA-IgG and CF-ICA at the diagnosis of Type 1 diabetes in 44 children. Spearman rank correlation coefficient: $r_{5}=0.66 ; p<0.001$

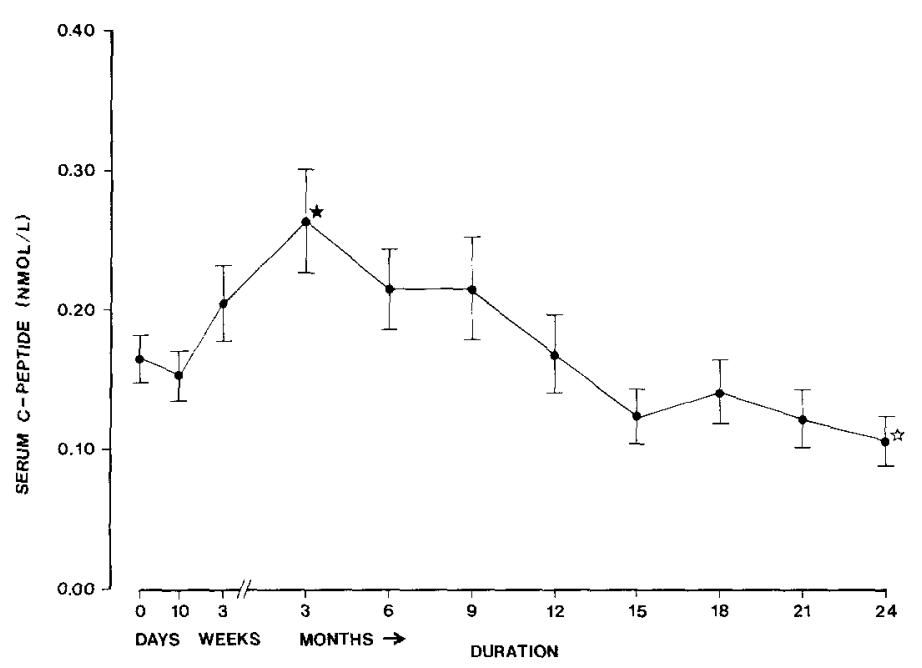

Fig.3. Serum C-peptide concentrations over the initial 2 years in 44 diabetic children. $p<0.05$ and $* p<0.01$ compared with the Cpeptide concentrations at onset

(group 2) respectively: (A) those who remained ICA-positive over the observation period; (B) those who became negative during the observation period; $(\mathrm{C})$ those who were ICA-negative from diagnosis.

\section{Statistical analysis}

The statistical analyses were performed using (1) cross-tabulation and $\chi^{2}$ statistics (2) in the case of normally distributed variables, the parametric one-way analysis of variance and (3) in the case of unequal distribution, the Spearman's rank correlation test, the Wilcoxon matched pairs signed-ranks test and the Kruskall-Wallis one-way analysis of variance. The results are expressed as mean \pm SEM.

\section{Results}

Thirty-seven patients ( $84 \%$ ) had ICA-IgG in their serum at diagnosis (Fig. 1), and 21 (48\%) remained positive for ICA-IgG over the observation period. Thus 16 patients became negative, while seven were continuously negative. There was no significant difference either in age at onset or in occurrence and duration of clinical remission between the groups (Table 1). The children in group $1 \mathrm{~A}$ had a shorter symptomatic period before diagnosis than those in group $1 \mathrm{~B}$ and they were less often ketoacidotic at the onset of the disease than the patients in the other two groups. Figure 1 shows the changes in titres of ICA-IgG over the initial 2 years. A considerable decrease occurred in the titres $\left(\chi_{\mathrm{df}=16}^{2}=64.2 ; p<\right.$ $0.001)$. One patient had an ICA-IgG titre of $1: 320$ at diagnosis, while six others had a titre of 1:160. After 2 years' duration, one child only had a titre of $1: 40$. The mean duration of ICA-IgG positivity in group $1 \mathrm{~B}$ was $14.5 \pm 0.9$ months.

Twenty-six children (59\%) had CF-ICA at diagnosis and eight (18\%) remained positive for CF-ICA over the observation period (Fig. 1 B). Eighteen children (41\%) were negative for CF-ICA when diagnosed, but one of those was found to be positive later (titre 1:1) and was omitted from the statistical evaluation. There were no significant differences between the three groups in the age at diagnosis, duration of symptoms before diagnosis, degree of ketoacidosis at diagnosis and occurrence and duration of clinical remission (Table 1). The changes in the titres of CF-ICA over the observation period (Fig. 1B) were similar to those for ICA-IgG titres. The highest titre of CF-ICA at diagnosis was $1: 20$, whereas one patient only had a titre $1: 4$ after 2 years. The decrease in the titres over the observation period was highly significant $\left(\chi_{\mathrm{df}=12}^{2}=42.6 ; p<0.001\right)$. There was a definite correlation between ICA-IgG and CFICA titres at diagnosis (Fig. 2). Five of six patients with an ICA-IgG titre of $1: 160$ at diagnosis were positive for CF-ICA (titres 1:20-1:4), the other one was negative despite repeated examination on separate blocks of substrate. The patient with the highest titre for ICA-IgG at diagnosis $(1: 320)$ was only weakly positive for $\mathrm{CF}$ ICA, but had been strongly positive for CF-ICA before the clinical manifestation of diabetes [8]. The children in group 2A had significantly higher titres for CF-ICA at diagnosis than those in group 2B $(p<0.01)$.

The mean serum C-peptide concentration in all 44 children studied was $0.17 \mathrm{nmol} / 1$ at diagnosis (range $0.00-0.44 \mathrm{nmol} / 1$; Fig. 3 ). Five patients had undetectable serum C-peptide levels at diagnosis, but a partial recovery of the $\beta$-cell function occurred in four of them within the first 3 months. The serum C-peptide concentration culminated in a mean of $0.26 \mathrm{nmol} / 1$ at 3 months' duration (range $0.00-0.93 \mathrm{nmol} / 1 ; p<0.01$ versus the levels at diagnosis). Subsequently there was a gradual decrease and at 2 years the mean concentration was $0.11 \mathrm{nmol} / 1$ (range $0.00-0.45 \mathrm{nmol} / 1 ; p<0.05$ versus diagnosis levels). At the end of the observation period serum C-peptide was undetectable in nine patients.

The mean serum C-peptide concentrations over the initial 2 years in the three groups of children classified on the basis of ICA-IgG status are illustrated in Fig- 


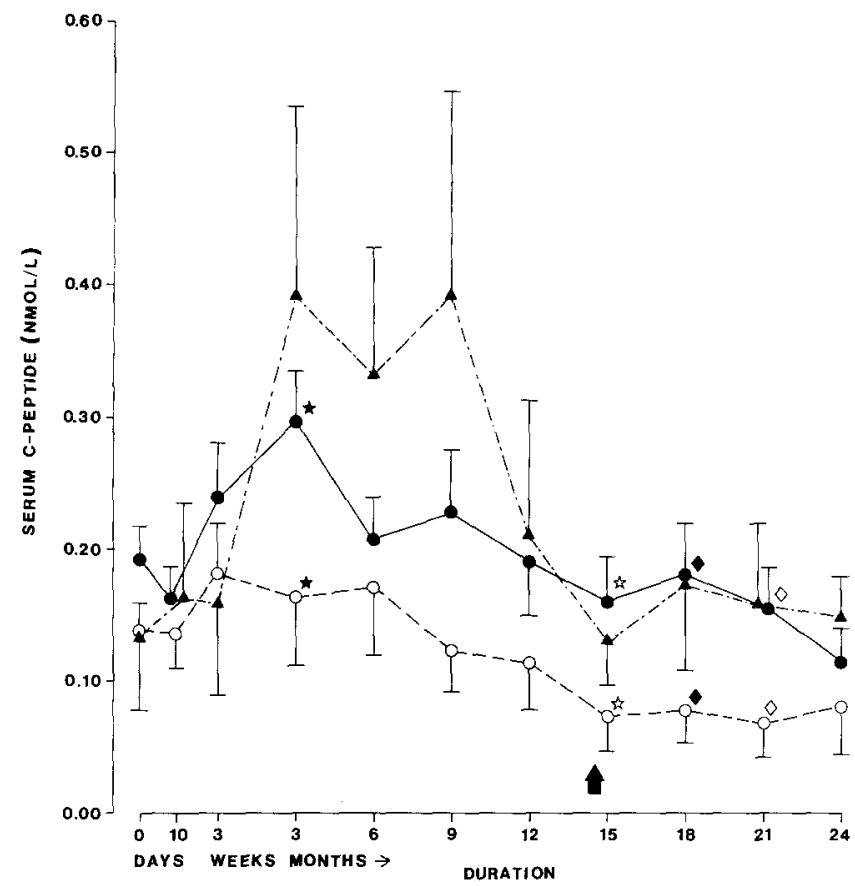

Fig.4. Mean serum C-peptide concentrations over the initial 2 years in the 21 children who were continuously positive for ICA-IgG $(-)$, the 16 children who became negative with regard to ICAIgG $\left(\mathrm{O}_{-}-\mathrm{O}^{-}\right)$and the seven children who were continuously negative for ICA-IgG (A-..-A). Arrow indicates the duration of ICA-IgG positivity in the children who became ICA-negative. $*$, is, $\diamond, \diamond p<0.05$

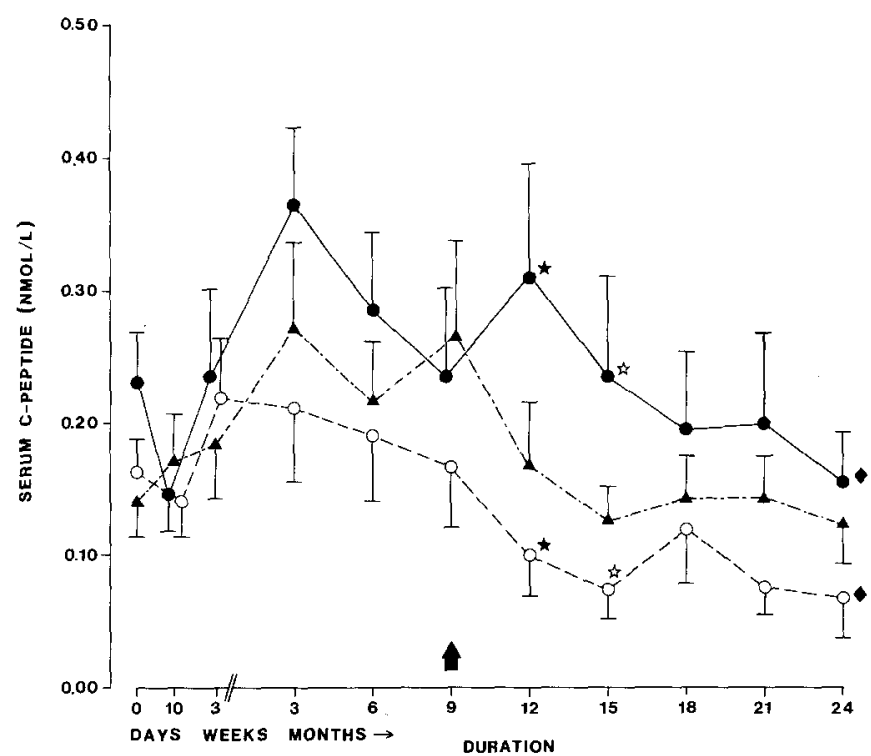

Fig.5. Serum C-peptide concentrations over the initial 2 years in the eight children who were continuously positive for CF-ICA (-), the 18 children who became negative with regard to CFICA $\left(\mathrm{O}_{--1}-\mathrm{O}\right)$ and the 17 children who were continuously negative for CF-ICA ( - - - A ). Arrow indicates the duration of CF-ICA positivity in the children who became ICA-negative. $*, *, \downarrow p$ $<0.05$

ure 4. The children in group $1 \mathrm{~A}$ had significantly higher serum C-peptide concentrations at 3 months and from 15 to 21 months than those in group $1 \mathrm{~B}$. However, when the eight patients, who were constantly CF-ICA posi- tive (group 2A) were omitted from group $1 \mathrm{~A}$ the significance found between the groups $1 \mathrm{~A}$ and $1 \mathrm{~B}$ disappeared. There were no significant differences between the three groups in the integrated serum C-peptide concentrations over the whole observation period (Table 1).

When the patients were grouped according to $\mathrm{CF}$ ICA status, there was a significant difference in the serum C-peptide concentrations at 12,15 and 24 months (Fig. 5). The children remaining CF-ICA-positive had the highest C-peptide levels, while those becoming negative had the lowest concentrations. The children in group 2A had a significantly higher integrated serum C-peptide concentration over the initial 2 years than those in group $2 \mathrm{~B}$ (Table 1).

The children who were constantly negative for CFICA had higher $\mathrm{HbA}_{1 \mathrm{c}}$ levels at the diagnosis of diabetes and 10 days later than those who became CF-ICA negative over the observation period (Fig.6). Subsequently there were no significant difference in the $\mathrm{HbA}_{1 \mathrm{c}}$ values between the three groups on any occasion.

\section{Discussion}

The prevalence of both ICA-IgG and CF-ICA at the clinical manifestation of diabetes found in this study is consistent with previous observations $[3,4]$. The present results clearly illustrate the evanescent character of cytoplasmic ICA and indicate a parallel occurrence of both types of ICA during the first years of Type 1 diabetes. Furthermore, a positive correlation between ICAIgG and CF-ICA titres was found at diagnosis. On the other hand, there were some patients with high ICAIgG titres that were negative or had very weak CF-ICA titres. This finding argues against the assumption that both tests measure exactly the same antibodies and that differences are found only as a result of the varying sensitivity of the two methods [22]. Our observations support the view presented by Bottazzo et al. [3] that the complement-fixation test detects a subspecies of ICA comprising a variable proportion of the total ICA determined by the conventional indirect immunofluorescence method.

In the present study, $89 \%$ of the diabetic children had evidence of $\beta$-cell secretory activity at diagnosis. This finding is in agreement with the observation of Ludvigsson and Heding [9]. Considering that all our patients had substantial hyperglycaemia at diagnosis, the initial C-peptide concentrations were conspicuously low, making up an average of $11 \%$ of the mean maximal C-peptide response to oral glucose seen in non-diabetic children and adolescents $(1.61 \pm 0.14 \mathrm{nmol} / 1, n=12$, mean age $10.7 \pm 1.6$ years; unpublished data). After discharge from hospital, serum C-peptide samples were taken between breakfast and lunch when the patients had slight hyperglycaemia or normoglycaemia. Hence the increase in the concentrations over the first 


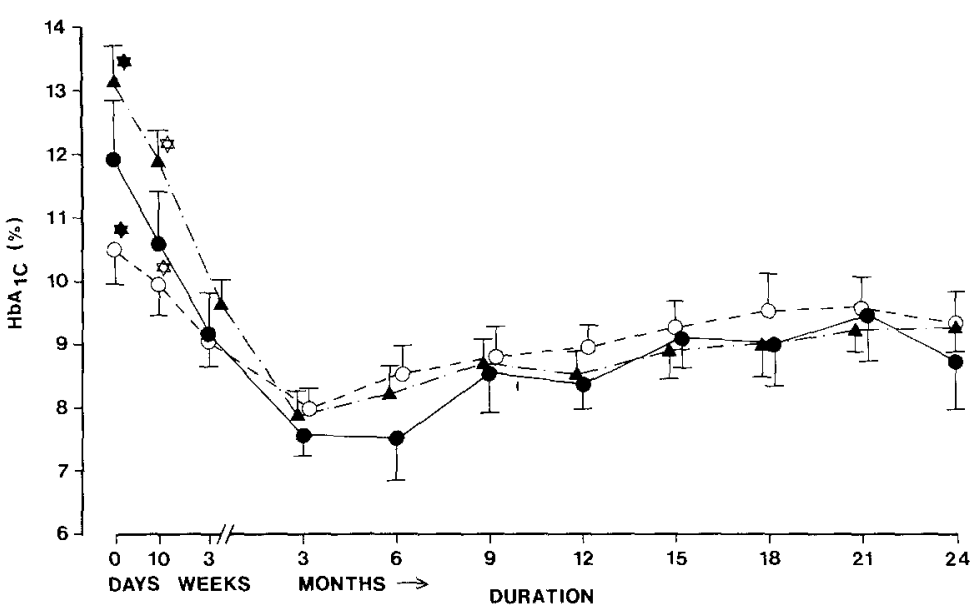

Fig. 6. $\mathrm{HbA}_{1 \mathrm{c}}$ over the initial 2 years in the eight children who were continuously positive for CF-ICA (-), the 18 children who became negative with regard to CF-ICA $\left(\mathrm{O}-\mathrm{O}_{-}\right)$and in the 17 children who were continuously negative for CF-ICA $(\boldsymbol{\Delta} \ldots \ldots)$, $p<0.01$
3 months represents a considerable, though partial, recovery of $\beta$-cell function. Thereafter, endogenous insulin secretion declined although three-quarters of the patients still had residual $\beta$-cell function after 2 years. Thirteen (34\%) showed serum C-peptide concentrations exceeding $0.10 \mathrm{nmol} / 1$ which has been regarded as reflecting a physiologically significant $\beta$-cell function in adult insulin-dependent diabetes [23].

Both Theophanides et al. [11] and Madsbad et al. [12] failed to demonstrate any association between the residual $\beta$-cell function and ICA-IgG in cross-sectional studies on diabetic patients with a mean duration longer than 10 years. It may be more justified, however, to focus attention on the relationship between the endogenous insulin secretion and ICA during the initial course of diabetes, since marked endogenous insulin secretion has been observed only during the first few years after the onset of diabetes [24, 25].

In the present study, the patients who became negative for ICA-IgG (group 1 B) had significantly lower Cpeptide concentrations on several occasions during the initial 2 years than those who remained ICA-IgG positive (group 1A). After excluding the eight patients who were constantly positive for CF-ICA, from the ICAIgG-positive group, however, there was no significant difference between the remainder in group $1 \mathrm{~A}$ and the other groups classified on the basis of the ICA-IgG status. Hence, the differences in C-peptide concentrations between groups $1 \mathrm{~A}$ and $1 \mathrm{~B}$ seem to be a consequence of the inclusion in group $1 \mathrm{~A}$ of patients who were CFICA-positive and had a high endogenous insulin secretion. There were no significant differences in the integrated serum C-peptide concentrations over the initial 2 years between all three groups.

In a previous cross-sectional study comprising 184 diabetic children and adolescents, we found a higher residual $\beta$-cell function in patients with CF-ICA than in those with ICA-IgG alone [15], indicating that the persistence of CF-ICA presupposes preservation of viable $\beta$ cells. The present finding that the patients who were constantly CF-ICA-positive had higher integrated serum $C$-peptide concentrations over the initial 2 years than those who became CF-ICA-negative supports the hypothesis that the persistence of CF-ICA is related to the preservation of functioning $\beta$ cells for antigenic stimulation. The significantly lower residual $\beta$-cell function in the patients in group $2 \mathrm{~B}$ on three occasions after becoming CF-ICA negative provides further evidence for this hypothesis. These results favour the point of view emphasized by Dean et al. [26] that CF-ICA should be separated from total ICA when studying the possible significance of ICA in the prediction of the manifestation and clinical course of Type 1 diabetes.

Absence of ICA at the clinical manifestation of Type 1 diabetes could indicate predominance of environmental factors in the aetiology and pathogenesis, whereas the presence of ICA emphasizes the role of mechanisms related to autoimmunity [27]. So far there is no evidence that individuals who are positive for CFICA in the prediabetic period become ICA-negative before diagnosis of the disease [5-8]. This fact supports the hypothesis that patients who are CF-ICA negative at the clinical onset have a different pathogenesis of their $\beta$-cell destruction than those who are positive for CF-ICA. Patients who were negative for CF-ICA had higher $\mathrm{HbA}_{1 \mathrm{c}}$ levels during the first 2 weeks than those who later became CF-ICA negative, which might also reflect differences in the pathogenetic events between the two groups. However, this study suggests that the $\beta$ cell damage is of the same magnitude in both groups of patients, since there were no significant differences in the serum C-peptide concentrations between CF-ICA negative and positive groups. On the other hand, our results indicate that the disappearance of CF-ICA after the clinical onset of diabetes is associated with an accelerated $\beta$-cell destruction. This observation is in accordance with that of Crossley et al. [13] who found that children with diminishing ICA titres had lower residual $\beta$-cell function at 6 months, duration than those with stable ICA titres or those who were constantly ICAnegative.

CF-ICA have been reported to appear in the circulation for as long as 3 years before the clinical manifestation of Type 1 diabetes $[5,6]$. The appearance of CF- 
ICA may be the first indicator of minimal $\beta$-cell damage. The finding of a long latent period preceding overt diabetes in persistently CF-ICA-positive subjects combined with the present observation of a higher residual $\beta$-cell function in diabetic patients remaining CF-ICApositive after the clinical onset of diabetes, suggests that CF-ICA are an immunogenic response to stimulation by islets that have been damaged but not totally destroyed.

Since the children who remained CF-ICA-positive had higher titres at diagnosis than those who became ICA-negative, high titres of CF-ICA at the clinical onset of Type 1 diabetes may indicate a protracted survival of functioning $\beta$ cells. Accordingly, determination of $\mathrm{CF}$ ICA titres in newly diagnosed diabetic patients and subjects at risk of developing diabetes could provide a potential measure for the identification of those individuals who might benefit from therapeutic efforts to limit $\beta$-cell damage at an early stage.

Acknowledgements. This work was supported by the Alma and K.A.Snellman Foundation, Oulu, Finland (A.M.), the Foundation for Diabetes Research in Finland (A.M.), and the Sigrid Jusélius Foundation (H.K. A.). We wish to thank Professor P. Häyry, Fourth Department of Surgery, University of Helsinki for collaboration in providing specimens of human pancreas, Dr. L. G. Heding, Novo Research Institute, Denmark for reagents for the C-peptide assay, and $\mathrm{S}$. Anttila and M. Vuoti for skilful technical assistance.

\section{References}

1. Lendrum R, Walker G, Gamble DR (1975) Islet-cell antibodies in juvenile diabetes mellitus of recent onset. Lancet 1: 880-883

2. Bottazzo GF, Mann JI, Thorogood M, Baum JD, Doniach D (1978) Autoimmunity in juvenile diabetics and their families. $\mathrm{Br}$ Med J II: $165-168$

3. Bottazzo GF, Dean BM, Gorsuch AN, Cudworth AG, Doniach D (1980) Complement-fixing islet-cell antibodies in Type-I diabetes: possible monitors of active beta-cell damage. Lancet 1: 668-672

4. Betterle C, Caretto A, Tiengo A, Trevisan A (1980) Complementfixing islet-cell antibodies in Type I diabetes and in susceptible patients with autoimmune diseases. Lancet 1: 1418-1419

5. Gorsuch AN, Spencer KM, Lister J, McNally JM, Dean BM, Bottazzo GF, Cudworth AG (1981) Evidence for a long prediabetic period in Type I (insulin-dependent) diabetes mellitus. Lancet 2: 1363-1365

6. Gorsuch AN, Spencer KM, Lister J, Wolf E, Bottazzo GF, Cudworth AG (1982) Can future Type I diabetes be predicted? A study in families of affected children. Diabetes 31: 862-866

7. Betterle C, Zanette F, Tiengo A, Trevisan A (1982) Five-year follow-up of non-diabetes with islet-cell antibodies. Lancet 1: 284-285

8. Jlonen J, Mustonen A, Åkerblom HK, Huttunen N-P (1980) Complement-fixing islet-cell antibodies before and after onset of insulin-dependent diabetes. Lancet 2: 805

9. Ludvigsson J, Heding LG (1978) Beta-cell function in children with diabetes. Diabetes 27 (Suppl 1): 230-234
10. Käär M-L, Knip M, Puukka R, Mustonen A, Ilonen J, Åkerblom HK (1984) Clinical course of insulin-dependent diabetes mellitus in children during the first years after onset. A longitudinal study. Pediatr Adolesc Endocr (in press)

11. Theophanides CG, Pyke DA, Watkins PJ (1978) Islet function in diabetics with persistent islet cell antibodies. Diabetes 27 (Suppl 1): 265-266

12. Madsbad S, Bottazzo GF, Cudworth AG, Dean B, Faber OK, Binder C (1980) Islet-cell antibodies and beta-cell function in insulindependent diabetics. Diabetologia 18: 45-47

13. Crossley JR, James AG, Elliott RB, Berryman CC, Edgar BW (1981) Residual B-cell function and islet cell antibodies in diabetic children. Pediatr Res 15: 62-65

14. Dorchy H, Lemiere B, Toussaint D, Gausset P (1981) Anticorps anti-cellules des ilots de Langerhans et spécifiques d'organes chez les jeunes diabétiques. Nouv Presse Med 10: 2795-2798

15. Mustonen A, Knip M, Åkerblom HK (1983) An association between complement-fixing cytoplasmic islet cell antibodies and endogenous insulin secretion in children with insulin-dependent diabetes mellitus. Diabetes 32: 743-747

16. Rittenhouse HG, Oxender DL, Pek S, Ar D (1980) Complementmediated cytotoxic effects on pancreatic islets with sera from diabetic patients. Diabetes 29:317-322

17. Eisenbarth GD, Morris MA, Scearce RM (1981) Cytotoxic antibodies to cloned rat islet cells in serum of patients with diabetes mellitus. J Clin Invest 67: 403-408

18. Sai P, Boitard C, Debray-Sachs M, Pouplard A, Assan R, Hamburger J (1981) Complement-fixing islet cell antibodies from some diabetic patients alter insulin release in vitro. Diabetes 30: 1051-1057

19. Heding LG (1975) Radioimmunological determination of human C-peptide in serum. Diabetologia 11: 541-548

20. Kuzuya H, Blix PM, Horwitz DL, Steiner DF, Rubenstein AH (1977) Determination of free and total insulin and C-peptide in insulin-treated diabetics. Diabetes 26: 22-29

21. Trivelli LA, Ranney HM, Lai T (1971) Hemoglobin components in patients with diabetes mellitus. N Engl J Med 284: 353-357

22. Riley WJ, Neufeld M, MacLaren NK (1980) Complement-fixing islet-cell antibodies: a separate species? Lancet 1: 1133

23. Gonen B, Goldman J, Baldwin D, Goldberg RB, Ryan WG, Blix PM, Schanzlin D, Fritz KJ, Rubenstein AH (1979) Metabolic control in diabetic patients. Effect of insulin secretory reserve (measured by plasma C-peptide levels) and circulating insulin antibodies. Diabetes 28: 749-753

24. Ludvigsson J, Heding LG, Larsson Y, Leander E (1977) C-peptide in juvenile diabetes beyond the postinitial remission period. Relation to clinical manifestations at onset of diabetes, remission and diabetic control. Acta Paediatr Scand 66: 177-184

25. Knip M, Puukka R, Käär M-L, Ảkerblom HK (1982) Remission phase, endogenous insulin secretion and metabolic control in diabetic children. Acta Diabetol Lat 19: 243-251

26. Dean BM, Pujol-Borrel R, Doniach D, Bottazzo GF (1983) Isletcell antibody determination: the essential message. Lancet 1: 654

27. Irvine WJ (1977) Classification of idiopathic diabetes. Lancet 1: $638-640$.

Received: 22 June 1983

and in final form: 9 August 1984

Dr. Aki Mustonen

Department of Paediatrics

University of Oulu

SF-90220 Oulu 22

Finland 